\title{
The promise of new institutionalism: explaining the absence of a World or United Nations Environment Organisation
}

\author{
Marjanneke J. Vijge
}

Accepted: 22 June 2012/Published online: 17 July 2012

(C) The Author(s) 2012. This article is published with open access at Springerlink.com

\begin{abstract}
In the past forty years, numerous proposals to improve the fragmented international environmental governance (IEG) system have been developed, many of which call for the establishment of an international environment organisation. Although governments and scholars agree that the system needs improvement, no such substantial reform has yet been undertaken. Based on the literature study and more than twenty interviews, this article explains the absence of an international environment organisation, using three theories of new institutionalism: historical, rational choice and discursive institutionalism. Through the notion of path dependency, historical institutionalism explains how the self-reinforcing cycle of a rather diffused development of the IEG system, characterised by incremental changes, has made the system more complicated and prevented substantial institutional change. Historical institutionalism also highlights power inequalities and lack of trust between nation-states, as well as turf wars between international organisations, as key explanatory factors hampering IEG reform. Rational choice institutionalism complements such explanations by showing how incremental institutional changes that do not add up to substantial reform are the result of the fact that neither nation-states nor international organisations are interested in establishing a powerful environment organisation that might encroach upon their sovereignty. Finally, discursive institutionalism suggests that the norm to do at least something to improve the IEG system has prompted nation-states to create "symbolic" institutions. The concept of socialisation helps to explain why incremental institutional developments within the UN system are more likely than substantial reform. The article shows that new institutionalism theories complement rather than contradict one another, resulting in a more holistic explanation of lack of IEG reform.
\end{abstract}

Keywords Institutional change - International environmental governance architecture/reform · New institutionalism · Political processes · World/United Nations Environment Organisation

M. J. Vijge ( $\bowtie)$

Environmental Policy Group, Wageningen University and Research Centre,

Hollandseweg 1, $6706 \mathrm{KN}$ Wageningen, The Netherlands

e-mail: marjanneke.vijge@wur.nl 


$\begin{array}{ll}\text { Abbreviations } \\ \text { CSD } & \text { Commission on Sustainable Development } \\ \text { EMG } & \text { Environment Management Group } \\ \text { EU } & \text { European Union } \\ \text { G77 } & \text { Group of 77 } \\ \text { GMEF } & \text { Global Ministerial Environment Forum } \\ \text { IEG } & \text { International Environmental Governance } \\ \text { MEAs } & \text { Multilateral Environmental Agreements } \\ \text { UN } & \text { United Nations } \\ \text { UNEO } & \text { United Nations Environment Organisation } \\ \text { UNEP } & \text { United Nations Environment Programme } \\ \text { US } & \text { United States of America } \\ \text { WEO } & \text { World Environment Organisation } \\ \text { WSSD } & \text { World Summit on Sustainable Development }\end{array}$

\section{Introduction}

The international environmental governance (IEG) system that seeks to reduce environmental degradation worldwide consists of many international environmental and nonenvironmental institutions and agreements that deal with often overlapping environmental issues. The United Nations Environment Programme (UNEP), which mandate is to coordinate the United Nations (UN) environmental activities, is closest to being the "leading global environmental authority" (UNEP 1997; par. 2). Other international institutions established to deal with environmental issues include the UN Commission on Sustainable Development (CSD), UNEP's Global Ministerial Environment Forum (GMEF) and UNEP's Environment Management Group (EMG) (Kanie 2007; Ivanova and Roy 2007). There are also many non-environmental regional and international organisations with environmental responsibilities, such as the Food and Agriculture Organisation, the World Health Organisation, the World Bank and many others. In addition, hundreds of Multilateral Environmental Agreements (MEAs) address various international, national and regional environmental issues, all operating with their own secretariat.

Within this complex international system for environmental governance, no single organisation, not even UNEP, possesses the authority or political strength to effectively coordinate all international environmental efforts (Inomata 2008). As has been long noted, UNEP lacks authority to fulfil such a role because of its insufficient and unreliable budget; its weak legal status; and the overlap of its mandate with those of many other international organisations that have environmental responsibilities but are not prepared to defer to UNEP (Tarasofsky 2002; Desai 2006; Bauer 2007; Biermann 2001; Biermann and Pattberg 2008; Andresen 2009; Drammeh 2009). While some argue that a system with loose, decentralised and dense networks of institutions and actors is the best design for managing global environmental problems (Oberthür and Gehring 2004; Najam 2002, 2003; see also Biermann et al. 2009; Biermann and Pattberg 2008; Kanie 2007), there is a general consensus that the IEG system is not adequate to deal with the many environmental problems in this world. Apart from insufficient coordination, factors contributing to such inefficiency include fragmentation of the system; overlapping and sometimes even conflicting mandates between organisations; the lack of enforcement, implementation and effectiveness of 
IEG; the lack of an overall vision; inefficient use of resources; and the many conflicts and imbalances that exist with other (particularly trade) regimes (Najam et al. 2006; Hoare and Tarasofsky 2007; Elliott 2005; Lodefalk and Whalley 2002; Biermann et al. 2009; Biermann and Pattberg 2008).

Since well before the establishment of UNEP in 1972, many proposals have been developed by countries, UN commissions and scholars to address these areas of concern. Many of these call for the establishment of a World or United Nations Environment Organisation (WEO/UNEO). The proposals differ in terms of the scale of the organisation, the functions it could fulfil, and the implications it has for the system. ${ }^{1}$ They are subject of many academic and political debates, including within the UN system. Despite the large number of proposals and the many debates that have taken place in the past decades, no action has been undertaken, nor any decisions made to embark upon a substantial reform of the IEG system, here equated with establishing an overarching international environment organisation. ${ }^{2}$ What has happened in the past decades, however, is a rapid growth in the number of additional (rather than overarching) environmental governance institutions that aim to improve the performance of the IEG system, here viewed as incremental changes to this system. As will be explained in more detail below, it has been argued that the myriad of such institutions has not been an improvement to the system, but has instead made the system less rather than more efficient.

This paper seeks to explain why, despite (or perhaps because of) the occurrence of such incremental changes, no substantial reform in the form of an international environment organisation has been undertaken, by applying the insights of new institutionalism to this case of (lack of) IEG reform. In doing so, the paper addresses a timely topic: despite the four decades of debates on the problems of and possible solutions for the increasingly fragmented system for international environmental governance, few studies have been carried out that seek to explain why these debates have not led to substantial institutional reform. ${ }^{3}$

Lack of IEG reform can be analysed through a wide variety of theoretical lenses. This paper focuses on the institutional aspects of the IEG system and the role actors play therein. It relies on three variants of new institutionalism: historical, rational choice and discursive institutionalism, in explaining policy outcomes in this case. As such, the paper is also interesting in assessing whether these three variants of new institutionalism yield complementary or contradictory explanations of the absence of an international environmental organisation. This fills a gap in the literature, given that relatively few scholars have sought to combine multiple theories in one analysis (Hall and Taylor 1996; Schmidt 2008a).

In explaining the lack of IEG reform, the paper focuses on two aspects that are somewhat distinctly addressed by each of the theories of new institutionalism. First, the paper focuses on the occurrence of incremental institutional change as opposed to substantial reform in the form of an international environmental organisation, paying special attention to the way in which a complex institutional structure like the IEG system evolves in what is perceived by many as suboptimal or inefficient, as explained above. Second, the

\footnotetext{
1 For a categorisation of the proposals, see Biermann (2000), Bauer and Biermann (2005) and Lodefalk and Whalley (2002).

2 Though there are other options for IEG reform under consideration, this paper mainly focuses on the reform option to establish a World or United Nations Environment Organisation.

3 Studies that address (part of) this question are among others Newell (2008), Vogler and Stephan (2007), Najam (2003).
} 
paper seeks to explain the persistence of the IEG institutional structure, shedding light on factors that hamper substantial IEG reform.

The analysis in this paper is based on primary and secondary sources, including twentytwo semi-structured interviews with scholars and practitioners in the field of international environmental governance (see list of interviewees). ${ }^{4}$

The outline of this paper is as follows. Section 2 introduces three variants of new institutionalism and identifies key concepts that each puts forward relating to the aspects of IEG reform identified above. Section 3 gives a historical overview of debates and developments relating to IEG reform, focusing on those within the UN system in the last four decades. Section 4 applies the concepts identified in Sect. 2 to the case of international environmental governance to explain lack of reform of the IEG system, in particular the lack of establishment of an international environmental organisation to date. The conclusion reflects on the utility of the three variants of new institutionalism in explaining this and assesses whether they yield complementary or contradictory explanations for the absence of an international environment organisation.

\section{The promise of new institutionalism}

Theories of new institutionalism are particularly useful in explaining (lack of) policy change, since they focus on how and why institutions originate, persist and evolve, and on the processes of institutional reproduction and institutionalisation ${ }^{5}$ (Alley 2001). The different varieties of new institutionalism differ significantly in how they explain institutional origins, continuities and changes. Despite this, they share the same focus as well as a common set of concerns and assumptions (Schmidt 2008a, b; Thelen 1999; Hall and Taylor 1996; Koelble 1995; Immergut 1998). These differences and similarities between variants of new institutionalism allow for comparison of their explanatory prowess, in this case by applying them to a specific case.

The paper distinguishes between historical, rational choice and discursive institutionalism, much along the same lines as Hall and Taylor's (1996) categorisation into historical, rational choice and sociological institutionalism, and the addition by Schmidt (2008a) of discursive institutionalism. More categorisations of new institutionalism exist, such as the one by Peters (2005) who also identifies normative, empirical and international institutionalism. Historical, rational choice and discursive institutionalism are chosen for the purpose of this analysis, because they cover the elements most useful in explaining lack of IEG reform, such as the influence of the institutional context on the development of specific institutions and power inequalities between actors (considered mainly by historical

\footnotetext{
4 The interviews provided information about the roles and opinions of key actors and factors that contribute to lack of IEG reform. The interviewees were selected on the basis of their involvement in the debates on the reform of the international environmental governance system. Interviewees included representatives from various UN environmental organisations and other international organisations dealing with environmental issues; representatives from non-governmental organisations directly involved in the debates; and scholars. The scholars who were interviewed were selected first, because they had developed proposals for an international environment organisation, and second, because of their expert knowledge and insights into the debates on IEG reform.

5 Though most of the varieties of new institutionalism have been developed for the study of domestic institutions, Jönsson and Tallberg (2008) show that different varieties of new institutionalism are also useful in international relations literature. They call on scholars of international relations to continue "drawing on institutional theories generated in the study of domestic institutions" (p. 21). This paper can be seen as a response to this call.
} 
institutionalism); the influence of actors' interests and behaviour on the emergence and persistence of institutions (considered mainly by rational choice institutionalism); and the influence of interactive processes and discourses on actors' behaviour and the institutional context (considered mainly by discursive institutionalism). ${ }^{6}$

This section identifies the key concepts that historical, rational choice and discursive institutionalism provide which can be useful in explaining: first, the occurrence of incremental institutional change; and second, the persistence of institutional structures. Section 4 then applies the theoretical precepts discussed to the case of international environmental governance (non-)reform in order to assess whether and how each of the three theoretical lenses helps to explain the absence of an international environment organisation.

\subsection{Historical institutionalism}

\subsubsection{Explaining incremental institutional change: path dependency}

According to historical institutionalism, actors' behaviour is largely determined by institutions influencing their choices as well as their worldviews and interpretations. In expanding on this view, historical institutionalism uses a combination of the so-called "calculus approach" and "cultural approach". The calculus approach holds that actors behave instrumentally and in a strategic way in order to maximise the attainment of their own interests (Schmidt 2008a). The cultural approach posits that behaviour is not entirely strategic, but influenced by actors' worldviews. Historical institutionalists believe that institutions provide "moral and cognitive templates for interpretation and action" (Hall and Taylor 1996; p. 939) by reinforcing some ideas or worldviews while undermining others (Koelble 1995; Jönsson and Tallberg 2008). Through this, institutions influence actors' behaviour not only by influencing the institutional context, and thus the ways in which their interests are maximised, but also by influencing actors' perceptions of what their interests and goals are (Koelble 1995).

A key factor for explaining incremental change is what historical institutionalists call "path dependency". Path dependency highlights how the institutional context, which is inherited from the past, influences developments and pushes these along so-called "trajectories" (Hall and Taylor 1996; Schmidt 2006, 2008b; Peters 2005; Thelen 1999; Pierson 2000). Though historical institutionalism views institutions as relatively persistent, it can account for institutional change through gradual adaption, causing ever greater change down the path by means of positive feedback. In this way, path dependency can be a useful concept in explaining the persistence of institutional structures and hence a lack of change (see below) but also in explaining the occurrence of incremental change and inefficiencies

\footnotetext{
${ }^{6}$ Normative institutionalism is not used in this paper, since many useful elements of this theory-especially its focus on norms of behaviour-are also covered by discursive institutionalism (Jönsson and Tallberg 2008; Schmidt 2008a). Discursive institutionalism was considered more useful for explaining the case of IEG (non-)reform, because apart from focusing on norms of behaviour, it also takes account of the interactive processes and the way in which actors are socialised in certain institutional structures. As for sociological institutionalism, apart from its focus on norms of behaviour, this theory mainly focuses on cultural aspects. Although a very broad definition of the concept of culture is used in this theory, the concept was not considered to add much to the other schools of thought in their explanation of institutional changes within the IEG system or the lack thereof. Empirical institutionalism focuses on the way in which the organisation of government institutions influence power structures and the political choices that are made. It was felt that many of these elements are also covered by historical institutionalism in its focus on path dependency and power inequalities.
} 
that may arise due to such change. Historical institutionalism posits that not only all pathdependent developments necessarily mean "virtuous" progress, but can instead also lead to inefficient, unintended or "vicious" outcomes (Lowndes 2005; p. 295), since not all developments are purposive. As Lowndes (2005; p. 295) argues: "Path dependency (...) creates a powerful cycle of self-reinforcing activity. The cycle, however, may be virtuous or vicious. There is no reason to assume that the option which becomes "locked in" is superior to the alternatives that were foregone". This can help to explain how institutional structures can emerge and persist that are perceived by many to be inefficient.

\subsubsection{Explaining the persistence of institutional structures: power inequalities}

Using the concept of path dependency, historical institutionalism can explain that possibilities for correcting such vicious developments are limited. Once "inefficient" structures are institutionalised, they influence the trajectories or institutional developments and make the move towards other-possibly more efficient-structures more difficult and more costly (Hall and Taylor 1996; Schmidt 2008b; Lowndes 2005). Historical institutionalists argue that staying on the path is more in actors' interest, since it is less costly than changing the path-i.e. bringing about substantial institutional change (Pierson 2000). Hence, creating new institutions is more difficult than "de-institutionalising" or changing old ones (Lowndes 2005; p. 294). This has to do as well with how institutional structures influence power relations between actors. According to historical institutionalism, institutions influence not only actors' choices but also the interactions between actors, since institutions are the main fora in which political debates or conflicts take place. Historical institutionalists generally conceive of power as actors' position vis-à-vis others (Schmidt 2008b). Since institutions privilege some interests - as posited by the above-mentioned cultural approach - they can grant certain actors more access over the decision-making process, and thus more power, than others. Historical institutionalists argue that such power inequalities in turn influence the trajectories of institutional developments (or lack thereof) (Hall and Taylor 1996; Schmidt 2006, 2008b; Immergut 1998; Koelble 1995; Lowndes 2005; Steinmo 2001). Hence, power relations between actors are influenced by and at the same time influence the context in which they are played out, which can be seen as another instance of the way in which path dependency influences (lack of) institutional developments.

\subsection{Discursive institutionalism ${ }^{7}$}

\subsubsection{Explaining incremental institutional change: socialisation}

Like historical institutionalism, discursive institutionalism (DI) makes use of the cultural approach in its explanation of actors' behaviour. Discursive institutionalism views actors'

\footnotetext{
7 In this paper, discursive institutionalism (DI) is used in its broadest sense, defined (and developed) by Schmidt (2008b; p. 3): "Discursive institutionalism is the term I use for all methodological approaches that take ideas and discourse seriously". Discursive institutionalism draws on a variety of discursive theories (see Schmidt 2008a, b) and yet constitutes its own analytical framework. Though the author is aware of the great variety of discursive (institutional) theories that exists, the focus on discursive institutionalism was chosen here because of its similar epistemological status compared to the other two new institutionalisms that are used in this paper. This made it possible to situate discursive institutionalism alongside the other new institutionalisms and compare the three of them in their explanation of the political institutional continuities and changes in the IEG system.
} 
behaviour as being heavily influenced by the way actors interpret the world around them (their world view). Actors are prevented or encouraged to use, change or create institutions in a certain way, because some patterns of behaviour are conventional or taken for granted (i.e. have become the norm of behaviour) while others are not. This can explain the occurrence of (incremental) institutional changes. Actors create certain routines or patterns of behaviour (also called institutions) that they generally adhere to. In other words, actors are socialised by the institutions in which or with which they work. Such socialisation influences actors' preferences, goals, the options they consider, and even the "very identities, self-images and preferences of the actors" (Hall and Taylor 1996; p. 939). As Connolly (1983 in Schmidt 2008a; p. 309) argued: "institutionalized structures of meaning (...) channel political thought and action in certain directions". Such directions, prompted by certain conventions or norms, can lead to institutional changes but are not necessarily the most optimal outcome (Hall and Taylor 1996; Schmidt 2008a).

\subsubsection{Explaining the persistence of institutional structures: discursive processes}

As the name already indicates, discursive institutionalism focuses mainly on the role of discourses in politics. Discourses can mean (1) discursive processes by which ideas are expressed and (2) the ideas that actors express (Schmidt 2008a, b). Both types of discourses can help to explain not only institutional change, but also lack thereof. Discourses enable actors to think, speak and act about or with institutions, and hence to change, maintain or create them, even while these actors are socialised by and are interacting within existing institutions (Hall and Taylor 1996). Institutions are an important influencing factor in the interactions between actors (i.e. as the context in which actors speak, think and act), and thus in how certain ideas are being discussed. Discursive institutionalism shows that an analysis of the nature of these interactions-or rather discursive processes-and the influence of institutions therein is worthwhile, since it influences their outcomes as well as what the involved actors consider to be likely or desirable outcomes (Schmidt 2008a). This can help to explain why certain ideas or discourses for action, such as undertaking substantial institutional reform, are less likely to happen than other, more conventional patterns of behaviour.

\subsection{Rational choice institutionalism}

\subsubsection{Explaining incremental institutional change: collective action dilemmas}

In its explanation of actors' behaviour, rational choice institutionalism draws on the calculus approach (see above). The calculus approach holds that actors behave entirely instrumentally and in a strategic way in order to maximise the attainment of what they perceive to be their own interests (Schmidt 2008a). Rational institutionalism tends to view the creation of institutions and the occurrence of (incremental) institutional changes as highly purposive, being established or embarked upon by actors who think this will maximise their interests (Hall and Taylor 1996). In such a view, rational choice institutionalism is rather functionalistic, putting much emphasis on the functions that institutions fulfil and the efficiencies they display. Rational choice institutionalism can, however, also explain inefficiencies in institutional structures by referring to deficiencies in these structures. An example is the case of a collective action dilemma. This is a situation in which, due to insufficient institutional structures, actors face insufficient information to make a judgment about the optimal outcome of their actions. Actors think they act in order 
to maximise the attainment of their preferences, but end up producing an outcome that neither represents actors' individual preferences, nor a collectively optimal outcome (Hall and Taylor 1996; Thelen 1999; Schmidt 2006; Immergut 1998).

\subsubsection{Explaining the persistence of institutional structures: calculus approach}

Using the calculus approach, rational choice institutionalism views actors interested in maximising their own interests as central in the political process. Institutions emerge and persist as a result of the interdependence and strategic interactions between these actors. The survival of institutions can be explained by the fact that they fulfil important functions that serve the interests of individual actors more than alternative institutional forms (Jönsson and Tallberg 2008; Alley 2001; Hall and Taylor 1996). Rational choice institutionalism explains institutional continuity by pointing to the fact that institutional changes only occur when actors feel that such change maximises their utility (Alley 2001). In addition, difficulties in overseeing the consequences of change as well as the high costs of such change can make actors reluctant to such reform (Steinmo 2001).

\section{History of the debates on IEG reform}

The current debates regarding the way to organise international environmental governance date back to the late 1960s and early 1970s. The growing concerns about environmental problems worldwide spurred the convening of the first environmental World Summit in 1972, the United Nations Conference on Human Environment in Stockholm. The creation of the United Nations Environment Programme that followed the Summit eased the concerns about ways to address these problems somewhat. Nevertheless, the structure of the system for international environmental governance was again debated during and in the run-up to the UN Conference on Environment and Development in Rio de Janeiro in 1992. This second environmental World Summit resulted in the establishment of the UN Commission on Sustainable Development (CSD), the task of which is to stimulate global, national and local action by UN bodies to promote sustainable development (Dodds et al. 2002).

Despite the establishment of yet another new body for environmental governance, dissatisfaction with the IEG system remained (Biermann 2000; Bauer and Biermann 2005). In 1998, the UN Task Force on Environment and Human Settlements concluded that the IEG system had substantial overlaps, unrecognised linkages and gaps, and that there was a need for more environmental coordination. In 1999, the General Assembly agreed to establish the United Nations Environment Management Group (EMG) and the Global Ministerial Environment Forum (GMEF) (High-level Forum of UNEMG 2006). Both were an attempt to increase the coherence in international environmental policy (High-level Forum of UNEMG 2006; Charnovitz 2002). The GMEF recommended that the third major environmental conference, the World Summit on Sustainable Development (WSSD) that took place in 2002 in Johannesburg, reviews the need to strengthen the architecture for international environmental governance based on an assessment of existing institutional weaknesses, future needs and a set of options for reform (UNEP 2001a). Although the WSSD called for a stronger collaboration within the UN system and underlined the need to eliminate duplication of functions and continue the attempt for greater integration, efficiency and coordination (High-level Forum of UNEMG 2006), scientists and non-governmental organisations argued that the Summit did not achieve much, as it was 
unable to deliver a solid proposal and only rephrased what had been agreed upon in other forums (Ivanova 2007a; Elliott 2005).

From 2004 to 2007, the proposal to upgrade UNEP to a fully fledged specialised agency, a United Nations Environment Organisation (UNEO), received special attention. In particular, France under President Jacques Chirac pushed for this proposal. In February 2007, the country convened the Paris conference for Global Ecological Governance to mobilise international action in support for a UNEO. The conference concluded with the Paris Call for Action, led by President Jacques Chirac. This was a call for "massive international action" that-according to the call-would have to manifest itself in the transformation of UNEP into a fully fledged international organisation (Paris Call for Action 2007). In the same year, France managed to bring together both developed and developing nations in the so-called "Group of Friends of the UNEO". This group was an effort to push for the establishment of a UNEO by building a strong coalition and break the impasse that existed due to differences in opinion on the future of the IEG system. Nevertheless, the group failed to enter into serious discussions on the possibility to set up a UNEO, as the idea did not have widespread support. The group merely consisted of about twenty-five members and was never very cohesive (Obermeyer 2009). The Group of Friends of the UNEO became inactive when Jacques Chirac left office in May 2007 (Haas 2009; Najam 2009; Dodds 2009; Dadema 2009; representative MinBuZa 2009a; Obermeyer 2009; Halle 2009; Martimort-Asso 2009).

In 2006, the High-Level Panel on United Nations System-Wide Coherence was established. This initiative could be seen as part of the wider UN reform process for a stronger, more effective and more coherent UN system (UN 2006). The High-Level Panel stated in its "Delivering as One" report that "[t]he international system is complex, fraught with duplication, and lacks coordination" (UN 2006; p. 20). UNEP was considered to be the right organisation to set global standards and coordinate system-wide environmental activities, but was considered "weak, under-funded and ineffective in its core functions" (UN 2006; p. 20). The High-Level Panel recommended that UN organisations cooperate more effectively and eliminate duplication and that UNEP be upgraded with a renewed mandate, improved funding and stronger coordination of system-wide environmental policies (UN 2006). Also, the Joint Inspection Unit, an assessment of the UN IEG system that was carried out in 2008, concluded that any future reform of the international environmental governance system needs to build on the reform of UNEP (Inomata 2008).

As a follow-up to the Delivering as One report, the General Assembly began informal consultations on the UN IEG system in 2006. The so-called "informal consultative process on the institutional framework for the UN's environmental activities" showed that, although there was consensus that the IEG system needs to be strengthened to improve coordination and coherence, there was no consensus on how this could be achieved. On the basis of this consultative process, a draft resolution called "Strengthening the environmental activities in the United Nations system" was submitted to the General Assembly in 2008 (GMEF 2009). The resolution was adjusted at its latest in January 2009 and was then still a draft version. The informal consultations led to the suggestion to launch formal negotiations by September 2009. However, the ambassadors who led the consultations and negotiations on the draft resolution concluded in February 2009 that the progress had been so slow that they had decided to stop the negotiations in the General Assembly altogether. The ambassadors requested the Global Ministerial Environment Forum in Nairobi to take over the discussions again (Reform the UN 2009; Dadema 2009; representative MinBuZa 2009a; Obermeyer 2009). During the twenty-fifth session of the GMEF in 
February 2009, a Consultative Group of Ministers or High-Level Representatives on International Environmental Governance was established, and the so-called "Belgrade process" was launched. After several meetings, the group presented a set of options for improving the IEG system to the GMEF at its eleventh special session in February 2010 (UNEP 2009). During this session, the consultative group identified several objectives and functions that the IEG system should have, as well as broader reform options for the UN international environmental governance system. A new Group of Ministers or High-Level Representatives was appointed to facilitate the implementation of the proposed incremental changes to UNEP as well as consider the broader reform options that were identified during the Belgrade process. During a session of the GMEF in February 2011 the group presented those options which received most support from governments, the so-called "NairobiHelsinki outcome". From May 2010 to June 2012 several preparatory and intersessional meetings and dialogues were being held to discuss the institutional framework for sustainable development in preparation for the Rio+20 UN Conference on Sustainable Development in June 2012. These meetings analysed the options described in the NairobiHelsinki outcome and considered IEG reform in the wider context of sustainable development. In the first half of 2012, informal negotiations in the UN General Assembly led to a "zero draft" outcome for the upcoming conference. During the conference itself the institutional framework for sustainable development was one of the central topics of discussion. One outcome of the conference regarding this topic was to replace the CSD with an "intergovernmental high-level political forum" on sustainable development. The aims of the forum are among others to set the agenda and build a platform for discussions on sustainable development, provide guidance and recommendations, and improve cooperation and coordination between organisations dealing with sustainable development as well as with financial and trade organisations. Governments also recommended to strengthen UNEP's role by among others establishing universal membership in the Governing Council and ensuring stable and increased financial resources (UN 2012; Global Environmental Governance Project 2011). Though some had high expectations that the Rio+20 conference would lead to decisions to substantially reform the IEG system, with some delegates strongly supporting one of the options of the Nairobi-Helsinki outcome to upgrade UNEP to a UNEO, the conference did not result in many new outcomes compared to previous fora and conferences. The outcomes of the conference are now expected to be taken forward by again starting formal negotiations within the UN General Assembly (IISD 2012; Biermann et al. 2012).

As is apparent from the above historical overview, actions have been taken regarding IEG reform: many discussions and assessments have taken place, and there have been numerous proposals to reform the IEG system. However, these debates are characterised by very little substantial institutional change; many speak of a "deadlock" in discussions and developments relating to IEG reform (Charnovitz 2005; Biermann 2009; Haas 2009; ICC representative 2009; Andresen 2009; Halle 2009; Amin 2009; representative of MinBuZa 2009a; Levy 2009). No move towards an international environment organisation has been made, which would constitute substantial reform of the IEG system.

\section{Explaining the absence of an international environment organisation}

In this section, the explanatory factors emphasised by the three variants of new institutionalism discussed in Sect. 2 are applied to discuss why, despite the many debates, proposals and assessments concerning the architecture of the IEG system, no decisions 
have been made to substantially reform this system through establishing an international environment organisation. This analysis focuses: first, on the occurrence of incremental institutional changes in the IEG system, focusing particularly on perceived inefficiencies that arise due to such changes; and second, on the persistence of institutional structures like the IEG system. Following this, the conclusion will compare and assess the three theories in terms of their usefulness in explaining IEG (non-)reform.

\subsection{Historical institutionalism}

\subsubsection{Explaining incremental institutional change: path dependency}

Using the concept of path dependency, historical institutionalism would explain the occurrence of incremental changes to the IEG system by studying the way in which the (historical) institutional context pushes developments along a certain path. As shown in the historical overview in Sect. 3, there has been a rapid growth in international institutions in the environmental arena over the past forty years (see also Ivanova 2005). Many of these relatively new institutions were efforts by the United Nations to coordinate environmental activities or discuss options to improve this coordination, UNEP being the first one, after which among others the EMG, GMEF and the CSD followed. The establishment of organisations within the IEG system has often been done without due consideration of how they might interact with the overall system (UNEP 2001a) and has to a large extent been ad-hoc, diffused and rather chaotic (Dodds et al. 2002). While some are of the opinion that the creation of these bodies has meant an improvement to the situation, many argue that some of these bodies only make the IEG system more complicated and increase the overlap and duplication between existing organisations that have environmental responsibilities (Desai 2006; Velasquez 2001). The concept of positive feedback or the earlier mentioned "powerful cycle of self-reinforcing activity" (Lowndes 2005; p. 295) that historical institutionalism provides us with can help to explain this. The concept sheds light on how the trajectory of establishing a series of incremental institutional tinkering can lead to ever greater change along the path: more (inefficient) institutions increase the complexity of the IEG system, which again leads to the further institutional tinkering in an effort to improve the system. Thus, the historical context of the IEG system warrants that incremental changes are more likely to happen than changing or dismantling (what has earlier been called "de-institutionalising") old ones, or setting up large new ones to coordinate the entire system (such as a WEO/ UNEO) (Ivanova 2005; Andresen 2001; Charnovitz 2005; Velasquez 2001; representative MinBuZa 2009b; Lowndes 2005). As the IEG case shows, not all institutional change is efficient or an improvement to the system, since not all path-dependent trajectories lead to "virtuous" progress. In the case of IEG (non-)reform, it has also been argued that incremental institutional changes can be worse than no action, since such changes have the effect of suppressing more substantial reform or "stacking" issues rather than resolving them (Stone 1972, in Ivanova 2007a). As a report on international environmental governance from the United Nations University claims with relation to the CSD: "Critics have (...) argued that the CSD can create a 'decoy effect' by considering sectoral issues that have been dealt with in more specialist fora for many years, thereby drawing attention from, or potentially conflicting with, other international decisions"

(Dodds et al. 2002, p. 33). 


\subsubsection{Explaining the persistence of institutional structures: power inequalities}

The "cycle of self-reinforcing activity" can also explain how a tendency to recycle debates concerning IEG reform prevents substantial change in the institutional structure for IEG. All regimes recycle issues to some extent, but such a phenomenon seems especially common in the environmental domain (Dodds et al. 2002). This can be seen from the fact that each new forum in which IEG reform is debated calls for the implementation of what a previous forum might already have proposed (for details, see Charnovitz 2002). As such, debates on IEG reform can resemble a "merry-go-round" whereby "things keep going around in circles" (Amin 2009) or where "debates have been circular" (Scanlon 2009). The CSD is the quintessential example of an institution that is said to "increasingly 'recycle' decisions already taken in other forums" (Dodds et al. 2002; p. 33). More generally, the tendency to recycle is evident from the multiple environmental conferences and debates over the years regarding the IEG system, its perceived weaknesses and prospects for reform, which have been repeated in different fora. As the historical overview in Sect. 3 shows, multiple declarations, assessments and resolutions have been adopted in the past forty years that call for an improvement of the institutional architecture of the IEG system. Rather than building up on one another, these declarations, assessments and resolutions seem to draw the same conclusion time, and again, namely that the system needs serious restructuring, the mandate of UNEP needs to be strengthened, overlap among existing organisations needs to be addressed, and efficiency, coordination and coherence of the system need to be enhanced. To date, however, no decisions have been made to substantially address these issues. Historical institutionalism would explain this by pointing to the way in which institutional structures guide trajectories, that is, the outcomes of the debates, along a certain path. In this case, the path that is created represents stagnation rather than progress towards decision-making, thereby resulting in persistence rather than substantial change of the institutional structure, representing what many perceive as a vicious rather than a virtuous development.

Historical institutionalism's focus on how power relations shape the emergence of institutions draws our attention to how power inequalities between countries (i.e. positions of countries vis-à-vis others) influence IEG reform outcomes. One hurdle to substantial IEG reform is that some of the most powerful states (e.g. the US and China) are opposed to or at best sceptical about such reform (Najam 2005). Furthermore, much of the conflict on whether and how to reform the IEG system has a North-South dimension. In a speech during a session of the GMEF in February 2009, the South-African Minister of Environmental Affairs and Tourism Marthinus van Schalkwyk, for example, spoke of a "widening trust gap" between North and South (Van Schalkwyk 2009; p. 1). Van Schalkwyk argued that it was necessary to "transform the politics of distrust, break the impasse and build a common vision for IEG reform" (Van Schalkwyk 2009; p. 3). As further documentation of power inequalities and different priorities, a report from the United Nations University stated that: "The inability of the international community to agree upon a common approach to sustainable development governance is rooted, to a large extent, in disparities between the perspectives and priorities of developed and developing countries" (Dodds et al. 2002; p. 28). Whereas countries in the North (especially in the European Union) would like to establish an organisation for the environment, developing countries (including more powerful ones like Brazil) prefer an organisation for sustainable development (Bauer 2007; Charnovitz 2005; representative MinBuZa 2009a; representative of UN Division of Sustainable Development 2009; representative ICC 2009; Dadema 2009; Andresen 2009). 
There are a number of reasons for why developing countries are at best hesitant towards establishing an international organisation for the environment. First, developing nations are concerned that an environment organisation will take attention away from issues of socioeconomic development and thus undermine developmental issues on the international political agenda (Ivanova 2005; Desai 2006; Hoare and Tarasofsky 2007; Bauer 2007; representative MinBuZa 2009a; Martimort-Asso 2009; Andresen 2009). Second, developing countries, which are often rich in natural resources, do not want the North to view their resources as global commons. They prefer to highlight their sovereign rights to develop and exploit these resources (Biermann 2002). A representative of the UN division of Sustainable Development summarised the view of Southern nations as follows: "the North used up everything first, and now they are telling us what to do" (representative of UN Division of Sustainable Development 2009; similar statements made by representative MinBuZa 2009b).

Developing countries are thus concerned that the establishment of an environment organisation may prioritise Northern over Southern interests. They see an international environment organisation as potentially another source of conditions and sanctions, possibly with enforcement powers comparable to the WTO (Biermann 2002; Charnovitz 2005; representative MinBuZa 2009a; Amin 2009). As one interviewee noted, "southern countries fear that the North will impose their will on them" through an international environment organisation (representative MinBuZa 2009a). This suggests that power inequalities and differential priorities of the more or less powerful nation-states influence prospects for IEG reform and are an important factor in explaining lack of progress towards substantial IEG reform.

As explained in Sect. 2, power inequalities not only influence the trajectories of institutional developments, but the institutional context also in turn influences power relations between involved actors. This can be seen, for example, from the fact that in 2009 the debates concerning IEG reform stagnated in the UN General Assembly in New York, where divisions between Northern and Southern countries on development-related and security issues are often prominent. The outcome was to relocate the debates concerning IEG reform back to Nairobi, under the auspices of UNEP. UNEP meetings in Nairobi are mostly concerned with environmental issues, backgrounding conflicts over sustainable development that is more prominent in New York (Dadema 2009; representative MinBuZa 2009a, b; Drammeh 2009).

Power struggles among international organisations-so-called "turf wars"-also help to explain why establishment of a new institution becomes difficult (Tarasofsky 2002; Desai 2006; Bauer 2007; Biermann 2001; Ivanova 2005; Andresen 2009; representative MinBuZa 2009b). Many of these organisations encroach upon UNEP's areas of work and are not prepared to give up their authority to UNEP or any overarching international organisation like a WEO or UNEO, since they often have an aversion to be coordinated (Ivanova 2005). This shows that an analysis of power defined as position vis-à-vis others, as emphasised by historical institutionalism, not only between nation-states but also between international organisations, helps to explain the lack of substantial IEG reform.

\subsection{Discursive institutionalism}

\subsubsection{Explaining incremental institutional change: socialisation}

Compared to historical institutionalism, discursive institutionalism offers a different explanation for the incremental institutional changes made to the IEG architecture over the 
last 40 years. Rather than seeing such changes as an outcome of path-dependent developments of institutional structures, discursive institutionalism would explain their establishment by pointing to the norm of behaviour to do at least something about the perceived need to address the multiple problems in the IEG system. According to Dimitrov (2005), the reason for incremental institutional change is that countries cannot afford to give the impression that they are not doing something about pressing environmental issues. It is a way to show that states are taking action on the issue of IEG reform without having to substantially change the UN environmental governance system. One interviewee argued that "organisational reform is the cheapest way to let others think that the UN is doing something. The CSD and the EMG [as examples of incremental institutional changes] can thus be called symbolic outputs" (Haas 2009). Another interviewee similarly argued that the CSD was established to foster the "impression, it might even be an excuse, that something is being done" (Andresen 2009). The norm to do at least something can be explained with the cultural approach. As argued in Sect. 2, institutions or the institutional context provide "moral and cognitive templates for interpretation and action" (Hall and Taylor 1996; p. 939) by reinforcing some ideas or worldviews. In contrast to the calculus approach (see Sect. 4.3), the cultural approach would assert that establishing symbolic institutions is not necessarily perceived to be in the actors' own interests, but that these institutions are nevertheless created because actors are socialised in the institutional context, providing them with the norm to take action.

\subsubsection{Explaining the persistence of institutional structures: discursive processes}

As argued in the previous section that applied historical institutionalism to the IEG case, the debates on IEG reform show a tendency to "recycle" decisions. Historical institutionalism helped to explain this by pointing to the path-dependent trajectories that the institutional structure of the IEG system generated. Discursive institutionalism offers a different explanation of this tendency to recycle, by focusing more on the nature of the discursive processes and the role of actors therein, rather than only on institutional structures. Discursive institutionalism would explain the fact that actors continuously (re)produce the same debates with the proposition that actors are socialised within these discursive processes. Since well before the establishment of UNEP, scholars, government officials and representatives of international organisations have developed about forty proposals and calls to establish an international environmental organisation. While none of these proposals have been realised to date, many of them have at some point been discussed in one or the other UN forum. Discursive institutionalists would explain this instance of (re)producing proposals, declarations and assessments by arguing that the actors (re)producing them are influenced by the norm to develop such declarations and proposals for change, even though they fail to actually realise such change. The concept of socialisation can thus help us explain how those involved in the IEG reform debates have been "circling around the same proposals and ideas for years" (Dadema 2009).

Another instance of socialisation can be found in how the debates on IEG reform focus too much on-or, as discursive institutionalists would say, are socialised towards- the institutional question. This is evident from the fact that often "the debate is not organised around the problem, but around the solution" (Martimort-Asso 2009). Institutional reform and the numerous specific proposals and calls for such reform are the focus of debate, without clear progress on what the problem is and what should be improved. The numerous assessments and working groups that have been undertaken or set up in the past several decades, and which are even now still being undertaken and called for, are indicative of the 
fact that no agreement has yet been reached on what exactly the problem is, apart from the IEG system being "inefficient", "incoherent" or "uncoordinated".

Another important aspect of the nature of the discursive processes that can help to explain the lack of change in IEG reform is that these processes (or debates) are scattered in many different locations around the world, which results in various inefficiencies, puts high demands on UN staff, and makes it difficult to keep in mind the bigger picture (UNEP 2001b; Ivanova 2005). As Van Schalkwyk said in a speech during a session of GMEF in February 2009: "I believe that it is not only the system that is fragmented, but also the debate on fixing the system" (Van Schalkwyk 2009; p. 1).

The concept of socialisation is also useful in explaining that-although there are other fora in which the interactive processes concerning the reform of the IEG system take place (such as the $\mathrm{G} 8^{8}$ )—most discussions remain within the UN system. The political procedures, dominant values and rules of the game in the UN influence possible outcomes as well as what actors consider to be possible outcomes. Thus, actors are socialised to debate the prospects for an international environmental organisation within rather than outside the UN system, with the latter hardly discussed (Levy 2009). Furthermore, within the UN, many discussions on IEG reform take place in forums, sessions or working groups organised by UNEP. The Global Ministerial Environment Forum, for example, consists only of environmental ministers since it falls under the purview of UNEP. A major hurdle, therefore, is that decisions that fall outside the mandate of environmental ministries cannot be taken within the GMEF, making it a relatively weak forum. Actors are nevertheless socialised to discuss the structure of the IEG system within (among others) the GMEF. Furthermore, since UNEP is so heavily involved in the discussions itself, the idea of bypassing UNEP is not considered a viable option in these discussions. A structural impediment to reform resulting from such dominant socialisation processes is that because UNEP only has fifty-eight members the Governing Council of UNEP cannot decide on reforming the IEG system. A decision to change the IEG system within the UN can only be taken in the UN General Assembly (Drammeh 2009). This can explain why proposals calling for incremental changes are much more dominant than the ones that advocate a total overhaul of the system or establishment of an international environmental organisation (Najam et al. 2006; Desai 2006).

\subsection{Rational choice institutionalism}

\subsubsection{Explaining incremental institutional change: collective action dilemmas}

Using the calculus approach, rational choice institutionalism holds that actors will only set up a new institution if it fulfils certain functions that serve their interests and help them maximise the attainment of their goals. As such, rational choice institutionalism explains the emergence of institutions by arguing that these are created by (a set of) actors who believe they can use them to their own advantage. In keeping with this logic, one explanation for UNEP being too weak to properly fulfil its mandate within the IEG system is that countries have decided to keep it weak (Dodds et al. 2002; Halle 2009). Most nation-states

\footnotetext{
${ }^{8}$ One example of a G8 meeting in which IEG reform was discussed was a meeting of environment ministers in Trieste in March 2001. The ministers stated that strengthening international environmental governance is important to meet the challenges of the twenty-first century (Sampson 2001).
} 
involved in the debates around IEG reform are more concerned with safeguarding their national interests than with collectively solving international environmental problems (Peichert 2007; Ivanova and Roy 2007; Najam et al. 2006; Halle 2009). As Ivanova and Roy (2007; p. 50) argue: "Conventional wisdom in international politics asserts that 'States use international institutions to further their own goals and design institutions accordingly'. Fearful of infringement upon their national sovereignty, governments deliberately create weak and underfunded international organizations with overlapping and even conflicting mandates" (see also Dadema 2009; Levy 2009). This seems to be borne out by the current state of the IEG institutional architecture, which consists of overlapping and weak institutions. The Commission on Sustainable Development has been mentioned earlier as an example of an institution that draws attention away from other, more powerful fora in which decisions regarding environmental issues are made. This may further isolate such decisions from important economic and financial issues with which these are inextricably linked (Dodds et al. 2002). Another institution that some consider to be relatively weak is the Global Ministerial Environment Forum (GMEF). As explained earlier, membership of this forum is confined to only environmental ministers, which means that certain crucial decisions regarding environmental issues cannot be taken within the GMEF. Applying the rational institutionalist perspective would suggest that a suboptimal outcome such as an inefficient IEG structure is in the interest of nation-states and international organisations that are part of the IEG system. Environmental issues are not always a priority concern for these actors, making them unwilling to give up their authority and collectively create a powerful international environment organisation that could make the IEG system more efficient. On the other hand, however, rational choice institutionalism may also view the IEG system as a collective action dilemma. The insufficient institutional structure of the IEG system may cause actors to face insufficient information to judge which actions produce an optimal outcome for them. By trying to pursue their individual interests, actors act in a way that produces an outcome that is collectively suboptimal or inefficient to properly deal with pressing environmental issues. Rational choice institutionalism neither helps us determine whether institutional structures are sufficient or insufficient for actors to make correct judgments about the outcome of their actions, nor whether a collective outcome is suboptimal (representing a collective action dilemma) or optimal (i.e. in the interest of actors).

\subsubsection{Explaining the persistence of institutional structures: calculus approach}

A rational institutionalist perspective would suggest that a collective action dilemma may be overcome by improving the IEG institutional architecture (e.g. by establishing an international environment organisation). At the same time, using the calculus approach, rational choice institutionalists believe that institutional structures are only changed or established by means of voluntary agreements between involved actors (Hall and Taylor 1996; Thelen 1999). Improving international environmental governance or establishing a

\footnotetext{
9 Some believe that even UNEP has deliberately been denied authority (Meyer-Ohlendorf 2006; Dodds et al. 2002; Halle 2009). Ivanova (2007b; pp. 37-38) quoted an officer who was involved in the preparatory process for the UNCHE: "UNEP was not to take any independent environmental initiatives itself. It was not to do things. It was to make a program but let others carry it out. In short, UNEP was to be essentially an idea-or perhaps more accurately an aspiration-institutionalized".
} 
WEO-like body therefore requires strong political will from nation-states. As widely noted by practitioners and scholars, such will is clearly missing (Hoare and Tarasofsky 2007; IEG Dossier 2009; Kanie 2007; Najam et al. 2006; Charnovitz 2005; Bauer 2007; Haas 2009; Andresen 2009; representative ICC 2009; Dodds 2009; Martimort-Asso 2009; Simonis 2009; Scanlon 2009). As Bauer (2007; p. 23) argued: "The bigger picture [in international environmental governance] is one of consistent unwillingness amongst governments to provide adequate means and substantive political decisions rather than symbolic actions" (see also Kanie 2007). In such a view, an efficient organisation is not politically feasible, as there is no political will among countries to create a powerful organisation, whereas a politically feasible organisation would be too weak and inefficient (Najam 2005; Martimort-Asso 2009; Halle 2009; Scanlon 2009). Furthermore, the topic of IEG reform is not considered to be a very urgent matter: it is not on nation-states' list of priority interests. Governments prefer to prioritise other pressing issues over IEG reform, such as international security issues, the financial crisis, climate change ${ }^{10}$ or the other seven clusters of the UN reform process, ${ }^{11}$ (Biermann 2009; Andresen 2009; Dodds 2009; Obermeyer 2009; Dadema 2009). The report of the co-chairs of the consultations on System-wide Coherence stated that they had not entered into detail on the environmental aspects, since "[i]t is simply the case that no appetite is detectable among Member States to pursue the Environment in the inter-governmental consultations on System-wide Coherences" (Kavanagh and Mahiga 2008; p. 28). According to Najam et al. (2006; p. 50), we currently lack "leaders whose personal ambitions align with the interests of the system as a whole".

Rational choice institutionalists argue that institutional change is costly and creates uncertainties that makes actors reluctant to initiate change. This is also the case with IEG reform, where countries are concerned about the complexities and costs of reforming the IEG system or establishing a specialised agency for the environment (IEG Dossier 2009). As one interviewee argued: "There is a gap between the political discourse and what is behind it, in terms of finance, time, idea. There is not a lot of national staff or finance involved in the discussion. This is an indicator of the motivation." (Martimort-Asso 2009). Although France was one of the countries that strongly advocated an international organisation for the environment, it made no commitments for funding or staff for such an organisation. An interviewee argued that he had "suspicions that they [the French] see it [pushing for a WEO/UNEO] as a cost-free way to be seen on the right sight of environmental debate. (...) There is not really a chance that the establishment of a UNEO or WEO will happen" (Levy 2009).

Going beyond countries, also international organisations and secretariats of Multilateral Environmental Agreements that are part of the IEG system have an interest in maintaining the highly fragmented system in order to maintain their autonomy (Charnovitz 2005). They

\footnotetext{
${ }^{10}$ Some argue that due to the concerns about major climatic changes, there is a heightened attention for environmental issues. Others, however, are of the opinion that the issue of climate change totally dominates the agenda and that this goes at the cost of the attention that governments spend on institutional reform of the IEG system and the possible establishment of an environment organisation (Biermann 2009; Andresen 2009; Dodds 2009; Obermeyer 2009; Dadema 2009).

11 These include: create a strong and accessible science base and ensure its interface with policy; create a global authoritative voice for the environment; ensure effectiveness, coherence and efficiency within the UN system; secure predictable and sufficient funds for IEG; and ensure a cohesive approach to meet country needs (GMEF 2010).
} 
Table 1 Explaining lack of IEG reform with the use of key concepts of new institutionalism

\begin{tabular}{|c|c|c|c|}
\hline & Historical institutionalism & $\begin{array}{l}\text { Discursive } \\
\text { institutionalism }\end{array}$ & $\begin{array}{l}\text { Rational choice } \\
\text { institutionalism }\end{array}$ \\
\hline $\begin{array}{l}\text { Explaining the } \\
\text { occurrence of } \\
\text { incremental } \\
\text { institutional (and } \\
\text { sometimes } \\
\text { inefficient) changes }\end{array}$ & $\begin{array}{l}\text { Path dependency helps } \\
\text { to explain the } \\
\text { emergence of a myriad } \\
\text { of institutions that make } \\
\text { the IEG system } \\
\text { increasingly complex } \\
\text { and difficult to change. } \\
\text { Through self- } \\
\text { reinforcing cycles in } \\
\text { path-dependent } \\
\text { developments, debates } \\
\text { stagnate rather than } \\
\text { trigger IEG reform, } \\
\text { leading to a "vicious" } \\
\text { rather than "virtuous" } \\
\text { process }\end{array}$ & $\begin{array}{l}\text { Socialisation: the } \\
\text { institutional context of } \\
\text { the IEG system } \\
\text { influences actors' world } \\
\text { view and can create the } \\
\text { norm to establish-not } \\
\text { necessarily efficient- } \\
\text { institutions or promote } \\
\text { incremental change } \\
\text { within the IEG structure }\end{array}$ & $\begin{array}{l}\text { Actors purposively create } \\
\text { efficient or inefficient } \\
\text { institutions because } \\
\text { they think these will } \\
\text { fulfil functions that are } \\
\text { in their interest. } \\
\text { Through this, a } \\
\text { collective action } \\
\text { dilemma may arise in } \\
\text { the form of an } \\
\text { increasingly complex } \\
\text { and inefficient IEG } \\
\text { system }\end{array}$ \\
\hline $\begin{array}{l}\text { Explaining the } \\
\text { persistence of } \\
\text { institutional } \\
\text { structures }\end{array}$ & $\begin{array}{l}\text { An analysis of power } \\
\text { inequalities draws } \\
\text { attention to a trust gap } \\
\text { between nation-states } \\
\text { and turf wars among } \\
\text { international } \\
\text { organisations, which } \\
\text { are a key hurdle to } \\
\text { change }\end{array}$ & $\begin{array}{l}\text { Discursive processes } \\
\text { influence actors' } \\
\text { actions and guide them } \\
\text { in more conventional } \\
\text { patterns of behaviour } \\
\text { that may hamper } \\
\text { substantial IEG reform }\end{array}$ & $\begin{array}{l}\text { Calculus approach: the } \\
\text { lack of political will to } \\
\text { substantially change the } \\
\text { IEG system and } \\
\text { incentives to retain the } \\
\text { status quo can explain } \\
\text { the lack of substantial } \\
\text { change in the form of } \\
\text { establishment of an } \\
\text { international } \\
\text { environment } \\
\text { organisation }\end{array}$ \\
\hline
\end{tabular}

fear to lose their work programme, budget or staff if reform of the IEG system entails elimination of duplication among organisations (Ivanova 2005; Peichert 2007). As a result, there is a general unwillingness among international organisations that are part of the IEG system to be coordinated, as also explained with the use of historical institutionalism in Sect. 4.1.

\section{Conclusion}

The three variants of new institutionalism analysed in this article take different approaches to explaining policy change (or lack thereof), each of which emphasises either the structures that constrain actors' behaviour, the power of actors to work with and change these structures, or both. Despite their differences, this analysis suggests that the different insights deriving from them supplement each another (see also Schmidt 2008a, b, Thelen 1999 and Hall and Taylor 1996 for a similar conclusion). This concluding section shows that the three varieties of new institutionalism are complementary rather than contradictory in their explanations of (1) the occurrence of incremental changes in the IEG system and (2) the persistence of the institutional structure for international environmental governance (see also Table 1). 


\subsection{Explaining incremental institutional change}

With the use of path dependency, historical institutionalism helps to explain how incremental changes in the form of a growing number of international organisations create trajectories that make the system more and more complicated and increases the overlap and duplication between organisations. This makes it increasingly difficult to establish an international environment organisation that aims to coordinate the entire system. The fact that not all outcomes of path dependency are "virtuous" can help to explain why some institutional arrangements that have emerged in the past forty years are thought to be ineffective or can even create "decoy effects". Similarly, because not all trajectories mean progress and because positive feedback can occur in such trajectories, there can be a tendency to "recycle" decisions in inefficient institutional structures.

Critics of historical institutionalism argue that it overemphasises institutional structures and their persistence and that it is much less able to explain why institutions emerge or institutional structures change, apart from stating that it is the outcome of path dependency (Alley 2001; Schmidt 2006; 2008b; Hall and Taylor 1996). Historical institutionalism's explanation that the complexity of the IEG system warrants the emergence of inefficient institutions, which in turn makes the system increasingly complex and difficult to change, can indeed be criticised for being tautological and historically deterministic. Both rational choice institutionalism and discursive institutionalism complement the insights deriving from historical institutionalism by focusing much more on how actors' actions are influenced by, influence and create institutions.

In its different explanation of actors' behaviour, rational choice institutionalism provides us with another explanation for why incremental institutional changes occur, using the calculus approach. Rational institutionalism views the origin of institutions as a result of conscious decisions by actors, in this case countries, who want to maximise their interest. In such a view, countries have deliberately established inefficient institutions because such institutions serve their interests in keeping their autonomy. A critique of rational institutionalism is that it relies on a "relatively thin" and "simplistic" explanation of actor's behaviour (Hall and Taylor 1996; p. 950-951). It neither helps to determine if actors are able to judge whether the outcome of their actions is in their own interest, nor the way in which institutions play a role in forming such a judgement (see also Hall and Taylor 1996). While rational choice institutionalism is thus not able to convincingly show whether a collective action dilemma exists in a given case, historical institutionalism is similarly not sufficiently clear about what "virtuous" and "vicious" developments are and who determines whether certain developments belong to the one or the other category.

Rather than concluding that actors' behaviour leads to collectively optimal or inefficient outcomes, or vicious or virtuous developments, discursive institutionalism focuses on how actors are socialised in a certain institutional context that shapes their perception of appropriate behaviour. Using the cultural approach, discursive institutionalism provides a different explanation for why actors have spurred incremental institutional changes, positing that actors establish institutions because they want to live up to the norm that they are at least taking some action to improve the system for international environmental governance, even if it entails creating symbolic institutions. In other words, the institutional context has socialised these actors into taking such actions. Though discursive institutionalism seems to provide a more complete explanation of how institutions emerge as compared to historical institutionalism, it is not able to establish in which cases and in what ways actors are socialised in certain institutional contexts (see also Alley 2001). The extent to which actors within the IEG system act in their own self-interest (even as this is being 
influenced by the institutions in which or with which they operate) or are guided by norms by which they are socialised is therefore difficult to determine.

\subsection{Explaining the persistence of institutional structures}

Using the calculus approach, rational choice institutionalism directs our attention to the lack of political will to establish a new international organisation for the environment as a key explanatory factor explaining the current state of IEG reform. Rational choice institutionalism also shows that actors are concerned about the costs and complexities surrounding the establishment of an international environment organisation. None of the advocates for such an organisation have shown willingness to invest sufficient resources in its establishment. Many actors that play a role in the IEG system have an incentive to maintain the status quo, since they have learned to use it to their advantage. To date, no agreement between actors has been made regarding the establishment of an international environment organisation.

An important criticism towards rational choice institutionalism is that it tends to downplay the important influence of power inequalities in the process of institutional change. Instead, it views the creation of new institutions as a voluntary agreement between relatively "equal and independent actors" (Hall and Taylor 1996; p. 952; see also Schmidt 2006). This ignores how powerful actors can promote or prevent certain institutional developments. On this point, historical institutionalism's focus on unequal power relations between actors can complement the insights of rational choice institutionalism. Such a focus directs our attention to the way in which a trust gap between Northern and Southern countries as well as the turf wars between international organisations within the IEG system make an agreement on IEG reform difficult to achieve.

Using the cultural approach, DI's focus on how actors are influenced by the discursive processes concerning IEG reform also helps to explain that proposals calling for incremental changes are much more dominant than those advocating a total overhaul of the system. In its focus on the discursive processes between actors rather than the pathdependent trajectories of historical institutionalism, discursive institutionalism is able to complement historical institutionalism's explanation on the tendency to "recycle" the debates on IEG reform. Discursive institutionalism explains such a tendency with the fact that actors are socialised in an "inward looking dialogue" that focuses too much on the institutional question rather than starting with a clear definition of the problem. The numerous assessments, declarations, proposals and calls for IEG reform are indicative of this: actors keep on (re)producing such assessments and proposals, even though these have not resulted in any specific agreements on what exactly the problem is, let alone on whether and how to substantially reform the IEG system. In addition, the fact that the debates on IEG reform are highly fragmented across different institutions and locations causes stagnation due to inefficiency and the inability to retain a good overview of the problem and possible solutions.

This paper showed that in emphasising either the institutional structures or the actors that influence and create institutions, historical institutionalism, rational choice institutionalism and discursive institutionalism provide very different yet complementary explanations for why no substantial reform of the IEG system has taken place to date. This suggests that the public policy debate can benefit from applying multiple theories in order to arrive at a more holistic understanding of complex political processes such as the lack of reform in international environmental governance. 
Acknowledgments I would like to thank Dr. Aarti Gupta for her great supervision and extremely valuable comments on earlier versions of the article.

Open Access This article is distributed under the terms of the Creative Commons Attribution License which permits any use, distribution, and reproduction in any medium, provided the original author(s) and the source are credited.

\section{References}

Alley, B. (2001). New institutionalist explanations for institutional change: A note of caution. Politics, 21(2), 137-145.

Andresen, S. (2001). Global Environmental Governance: UN fragmentation and coordination. In O. S. Stokke \& Ø. B. Thommessen (Eds.), Yearbook of international co-operation on environment and development 2001/2002 (pp. 19-26). London: Earthscan Publications.

Bauer, S. (2007). The catalyst conscience: UNEP's secretariat and the quest for effective international Environmental Governance. Global governance working paper, No 27. Amsterdam et al.: The Global Governance Project. Retrieved January 18, 2009, from www.glogov.org.

Bauer, S., \& Biermann, F. (2005). The debate on a World Environment Organization: An introduction. In F. Biermann \& S. Bauer (Eds.), A World Environment Organization: Solution or threat for effective international Environmental Governance? (pp. 1-23). Burlington, USA: Ashgate.

Biermann, F. (2000). The case for a World Environment Organization. Environment, 42(9), $22-32$.

Biermann, F. (2001). The emerging debate on the need for a World Environment Organization: A commentary. Global Environmental Politics, 1(1), 45-55.

Biermann, F. (2002). Strengthening Green Global Governance in a Disparate World Society: Would a World Environment Organisation Benefit the South? International Environmental Agreements: Politics, Law and Economics, 2(4), 297-315.

Biermann, F., \& Pattberg, P. (2008). Global Environmental Governance: Taking stock, moving forward. Annual Review of Environment and Resources, 33, 277-294.

Biermann, F., Pattberg, P., Van Asselt, H., \& Zelli, F. (2009). The fragmentation of global governance architectures: A framework for analysis. Global Environmental Politics, 9(4), 14-40.

Biermann, F., Abbott, K., Andresen, S., Bäckstrand, K., Bernstein, S., Betsill, M. M., et al. (2012). Navigating the Anthropocene: Improving earth system governance. Science, 335, 1306-1307.

Charnovitz, S. (2002). A World Environment Organization. Working paper of the International Environmental Governance Reform Project of the United Nations University Institute of Advanced Studies. Retrieved October 16, 2009 from http://www.unu.edu/inter-linkages/docs/IEG/Charnovitz.pdf.

Charnovitz, S. (2005). Towards a World Environment Organization: Reflections upon a vital debate. In F. Biermann \& S. Bauer (Eds.), A World Environment Organization: Solution or threat for effective international Environmental Governance? (pp. 87-115). Burlington, USA: Ashgate.

Desai, B. H. (2006). UNEP: A global environmental authority? Environmental Policy and Law, 36, 3-4.

Dimitrov, R. S. (2005). Hostage to norms: States, institutions and global forest politics. Global Environmental Politics, 5(4), 1-24.

Dodds, S. E. H., Chambers, W. B., \& Kanie, N. (2002). International Environmental Governance: The question of reform: key issues and proposals, preliminary findings. Retrieved March 24, 2009 from United Nations University Institute of Advanced Studies (UNU-IAS) website:http://www.ias.unu.edu.

Elliott, L. (2005). The United Nations' record on Environmental Governance: An assessment. In F. Biermann \& S. Bauer (Eds.), A World Environment Organization: Solution or threat for effective international Environmental Governance? (pp. 27-56). Burlington, USA: Ashgate.

Global Environmental Governance Project. (2011). "The political process of IEG”. Retrieved April 6, 2011 from, http://www.environmentalgovernance.org/reform/the-political-process-of-ieg/.

GMEF (2009, February 16-20). Policy issues: International Environmental Governance. Report by the Executive Director. Twenty-fifth session of the Governing Council/Global Ministerial Environment Forum. UNEP/GC.25/3, Nairobi.

GMEF (2010, February 24-26). Emerging policy issues: Environment in the multilateral system: International Environmental Governance: Outcome of the work of the consultative group of ministers or highlevel representatives. Eleventh special session of the Governing Council/Global Ministerial Environment Forum. UNEP/GCSS.XI/4, Bali.

Hall, P. A., \& Taylor, R. C. R. (1996). Political science and the three new institutionalisms (pp. 936-957). XLIV: Political Studies. 
High Level Forum of UNEMG. (2006, January 24). High-level Forum of the United Nations Environment Management Group: Discussion paper by the Chair. First meeting, Geneva. Retrieved February 17, 2009 from http://www.unemg.org/document/HLFDocs.php.

Hoare, A., \& Tarasofsky, R. (2007, July). International Environmental Governance. Report of a Chatham House Workshop. Chatham House (The Royal Institute of International Affairs), London.

IEG Dossier. (2009). International Environmental Governance. Retrieved February 17, 2009, from http:// www.stakeholderforum.org/.

Immergut, E. M. (1998). The theoretical core of the new institutionalism. Politics Society, 26(5), 5-34.

Inomata, T. (2008). Management review of Environmental Governance within the United Nations system. Joint Inspection Unit of the United Nations. JIU/REP/2008/3, Geneva.

International Institute for Sustainable Development (IISD). (2012, June 25). Summary of the United Nations conference on sustainable development: 13-22 June 2012. Earth Negotiations Bulletin, 27(51), 1-24. Retrieved 4 July 2012 from http://www.iisd.ca/download/pdf/enb2751e.pdf.

Ivanova, M. H., \& Roy, J. (2007). The architecture of global Environmental Governance: Pros and cons of multiplicity. In L. Swart \& E. Perry (Eds.), Global Environmental Governance. Perspectives on the current debate (pp. 48-66). New York: Center for UN Reform Education.

Ivanova, M. H. (2005). Can the anchor hold? Rethinking the United Nations Environment Programme for the 21st Century. Yale F\&ES P Publication Series, No. 7, 1-55.

Ivanova, M. H. (2007a). Appendix 3: International Environmental Governance workshop, session 2: Options and implications. In A. Hoare \& R. Tarasofsky (Eds.), (2007, July). International Environmental Governance. (pp. 20-33). Report of a Chatham House Workshop. Chatham House (The Royal Institute of International Affairs), London.

Ivanova, M. H. (2007b). Moving forward by looking back: Learning from UNEP's history. In L. Swart \& E. Perry (Eds.), Global Environmental Governance: Perspectives on the current debate (pp. 26-47). New York: Center for UN Reform Education.

Jönsson, C., \& Tallberg, J. (2008). Institutional Theory in International Relations'. In J. Pierre, B. G. Peters \& G. Stoker (Eds). Debating institutionalism. Manchester University Press, Manchester, NY. Retrieved April 11, 2011 from http://www.uni-muenster.de/Politikwissenschaft/Doppeldiplom/docs/IIR.pdf.

Kanie, N. (2007). Governance with multilateral environmental agreements: A healthy or ill-equipped fragmentation? In L. Swart \& E. Perry (Eds.), Global Environmental Governance. Perspectives on the current debate (pp. 67-86). New York: Center for UN Reform Education.

Kavanagh, P., \& Mahiga, A. (2008, July 21). System-wide coherence: Report of the co-chairs of the 62nd general assembly consultations. Retrieved March 19, 2009 from http://www.undg.org/docs/9447/ swcreport210708.pdf.

Koelble, T. A. (1995). The new institutionalism in political science and sociology. Comparative Politics, 27(2), 231-243.

Lodefalk, M., \& Whalley, J. (2002). Reviewing proposals for a world environmental organisation. The World Economy, 25, 601-617.

Lowndes, V. (2005). Something old, something new, something borrowed... How institutions change (and stay the same) in local governance. Policy Studies, 26(3), 291-309.

Meyer-Ohlendorf, N. (2006). Would a United Nations Environment Organization help to achieve the millennium development goals? RECIEL, 15(1), 23-29.

Najam, A. (2002). The case against GEO, WEO, or whatever-else-EO. In D. Brack \& J. Hyvarinen (Eds.), Global environmental institutions: Perspectives on reform (pp. 367-384). London: Royal Institute of International Affairs.

Najam, A. (2003). The case against a New International Environmental Organization. Global Governance, $9(3), 367-384$.

Najam, A. (2005). Neither necessary, nor sufficient: Why organizational tinkering won't improve Environmental Governance. In F. Biermann \& S. Bauer (Eds.), A World Environment Organization: Solution or threat for effective international Environmental Governance? (pp. 235-256). Burlington, USA: Ashgate.

Najam, A., Papa, M., \& Taiyab, N. (2006). Global Environmental Governance: A Reform Agenda. Winnipeg, Canada: International Institute for Sustainable Development \& Ministry of Foreign Affairs Denmark.

Newell, P. (2008). The political economy of Global Environmental Governance. Review of International Studies, 34(3), 507-529.

Oberthür, S., \& Gehring, T. (2004). Reforming International Environmental Governance: An institutionalist critique of the proposal for a World Environment Organisation. International Environmental Agreements: Politics, Law and Economics, 4, 359-381. 
Paris Call for Action. (2007, February 3). Retrieved May 22, 2009 from the website of the French President: http://www.elysee.fr/elysee/elysee.fr/anglais/speeches_and_documents/2007/ paris_call_for_action.71492.html.

Peichert, $\bar{H}$. (2007). Appendix 2: International Environmental Governance Workshop, session 1: What needs to be fixed and what are the optimal outcomes? In A. Hoare \& R. Tarasofsky (Eds.), (2007, July). International Environmental Governance. (pp. 14-19). Report of a Chatham House Workshop. Chatham House (The Royal Institute of International Affairs), London).

Peters, G. (2005). Institutional theory in political science: The new institutionalism. London: Continuum.

Pierson, P. (2000). Increasing returns, path dependence, and the study of politics. The American Political Science Review, 94(2), 251-267.

Reform the UN. (2009, March 19). Efforts to Reform International Environmental Governance Stall. Retrieved June, 26, 2009, from http://www.reformtheun.org/index.php/eupdate/4769.

Sampson, G.P. (2001). Inter-linkages: Strategies for bridging problems and solutions to work towards sustainable development. Background note for Working Group One on the World Summit for Sustainable Development, International Eminent Persons Meeting, United Nations University Centre, Foreign Ministry of Japan, Environment Ministry of Japan, Global Legislators Organization for a Balanced Environment.

Schmidt, V. A. (2006). Give peace a chance: Reconciling the four (not three) new institutionalisms. (Paper prepared for presentation for the National Meetings of the American Political Science Association, Philadelphia, Aug. 31-Sept. 1).

Schmidt, V. (2008a). Discursive institutionalism: The explanatory power of ideas and discourse. The Annual Review of Political Science, 11, 303-326.

Schmidt, V. (2008b, August 27). From historical institutionalism to discursive institutionalism: Explaining change in comparative political economy. Paper prepared for presentation at the 104th Annual Meeting of the American Political Science Association, Boston.

Steinmo, S. (2001). The new institutionalism. In B. Clark \& J. Foweraker (Eds.), The encyclopedia of democratic thought. London: Routlege.

Tarasofsky, R. (2002). International Environmental Governance: Strengthening UNEP. Retrieved February, 19, 2009, from United Nations University Institute of Advanced Studies (UNUIAS) website: http:// www.unu.edu/inter-linkages/docs/IEG/Tarasofsky.pdf.

Thelen, K. (1999). Historical institutionalism and comparative politics. Annual Review of Political Science, 2, 369-404.

UNEP. (1997). Nairobi declaration. Retrieved March 3, 2009 from http://www.unep.org/Documents. multilingual/Default.asp?DocumentID=287\&ArticleID=1728\&l=en.

UNEP. (2001a, April 18). International Environmental Governance, report of the executive director. First meeting Open-Ended Intergovernmental Group of Ministers or Their Representatives on the International Environmental Governance. UNEP/IGM/1/2, New York.

UNEP. (2001b, August 2). International Environmental Governance, report of the executive director. Second meeting Open-ended intergovernmental group of ministers or their representatives on the international environmental governance. UNEP/IGM/2/6, Bonn.

UNEP. (2009, June 27-28). Belgrade process, moving forward with developing a set of options on International Environmental Governance, co-chairs summary. First meeting of the Consultative Group of Ministers or High-level Representatives on International Environmental Governance, Belgrade. Retrieved August 6, 2009, from http://www.unep.org/environmentalgovernance/Introduction/tabid/ 341/language/en-US/Default.aspx.

United Nations. (2006, November 9). Delivering as one. Report of the Secretary-General's High-Level Panel on UN System-wide Coherence in the Areas of Development, Humanitarian Assistance and the Environment, New York. Retrieved February 18, 2009 from http://www.un.org/events/panel/resources/ pdfs/HLP-SWC-FinalReport.pdf.

United Nations. (2012, June 19). The future we want. Agenda item 10: Outcome of the Conference. Rio+20 United Nations Conference on Sustainable Development. A/CONF.216/L, Rio de Janeiro.

Van Schalkwyk, M. (2009, February 19). Keynote address by Marthinus van Schalkwyk, South African Minister of Environmental Affairs and Tourism, at the plenary Ministerial consultations on International Environmental Governance: Help or hindrance? Twenty-fifth session of the Governing Council/ Global Ministerial Environment Forum, Nairobi. Retrieved June 16, 2009 from http://www.unep.org/ GC/GC25/Docs/Final_UNEP_speech_IEG\%5B1\%5D_18_feb_09.pdf.

Velasquez, J. (2001, September 3-4). Inter-linkages: Strategies for bridging problems and solutions in the further implementation of sustainable development. National Framework for Inter-Linkages: Bridging Problems and Solutions to Work toward the Further Implementation of Agenda 21. (Paper presented 
for the United Nations University Global Information Centre at the World Summit for Sustainable Development during International Eminent Persons Meeting on Inter-linkages, Johannesburg).

Vogler, J., \& Stephan, H. R. (2007). The European Union in Global Environmental Governance: Leadership in the making? International Environmental Agreements, 7, 389-413.

\section{List of interviewees}

Amin, Adnan Z. Director of the UN System Chief Executive Board for Coordination (CEB), New York. Telephone interview 28-07-2009.

Andresen, Steinar. Professor at the Fridtjof Nansen Institute, Norway. Telephone interview 08-06-2009.

Biermann, Frank. Professor of Political Science and Environmental Policy Sciences at the Vrije Universiteit in Amsterdam. Interview 18-05-2009, Amsterdam.

Dadema, Martijn. Representative of MinBuZa, Dutch ministry of Foreign Affairs, permanent mission of the Netherlands to the UN in Nairobi. Telephone interview 23-07-2009.

Dodds, Felix. Executive Director of Stakeholder Forum for a Sustainable Future. Telephone interview 16-06-2009 and 05-04-2011.

Drammeh, Halifa Omar. Former Director of the Environment Management Group; former Deputy Director of the Division of Policy Development and Law. Telephone interview 15-05-2009.

Haas, Peter M. Professor at the Department of Political Science Faculty at University of Massachusetts. Telephone interview 26-05-2009.

Halle, Mark. European Representative and Director, Trade and Investment at the International Institute for Sustainable Development (IISD), Geneva. Telephone interview 26-06-2009.

Kakabadse, Yolanda. General Counsel and former Executive President of Fundación Futuro Latinoamericano in Ecuador, and former President of IUCN, Ecuador. Telephone interview 21-07-2009.

Levy, Marc. Deputy Director of the Centre for International Earth Science Information Network (CIESIN), Columbia University, New York. Telephone interview 23-06-2009.

Martimort-Asso, Benoît. In charge of the International Environmental Governance Programme at Sustainable Development and International Relations Institute (IDDRI), Paris. Telephone interview 29-062009.

Najam, Adil. Frederick S. Pardee Professor of Global Public Policy at Boston University. Interview 18-062009, Wageningen.

Obermeyer, Werner. Chief Inter-Agency Affairs, UNEP, New York. Telephone interview 23-06-2009.

Representative of MinBuZa. (2009a). Dutch ministry of Foreign Affairs, permanent mission of the Netherlands to the UN in New York. Telephone interview 22-06-2009.

Representative of MinBuZa. (2009b). Vlugt, Jurjen van der, Dutch ministry of Foreign Affairs, permanent mission of the Netherlands to UNEP, The Hague. Telephone interview 10-07-2009.

Representative of the International Chamber of Commerce (ICC). Former representative of the World Business Council for Sustainable Development (WBCSD), member of the Environment and Energy Commission, permanent representative in Geneva. Telephone interview 04-06-2009.

Representative of United Nations Division of Sustainable Development in New York. Telephone interview 19-06-2009.

Scanlon, John. Principal Advisor to the Executive Director on Policy and Programme at UNEP, Nairobi. Telephone interview 16-07-2009.

Simonis, Udo E. Professor Environmental Policy at the Social Science Research Centre Berlin (WZB, Wissenschaftszentrum Berlin für Sozialforschung) Berlin. Telephone interview 29-06-2009.

Teehankee, Manuel A.J. Chair of the WTO Committee on Trade and Environment, Philippine permanent representative to the World Trade Organization in Geneva. Telephone interview 07-07-2009.

Whitten, Tony. Senior Biodiversity Specialist for the East Asia and Pacific Region at the World Bank, Washington, D.C. Telephone interview 24-07-2009.

WTO representative. Counselor of the Trade and Environment Division, Geneva. Telephone interview 10-06-2009. 